\title{
Karakteristik Torrefaksi dan Densifikasi Limbah Tandan Kosong Kelapa Sawit
}

\author{
Maryudi* \\ Program Studi Teknik Kimia, Universitas Ahmad Dahlan, Kampus III, Jln. Supomo, Janturan, Warungboto, \\ Umbulharjo, Yogyakarta 55164 \\ *Email: maryudi@che.uad.ac.id
}

\begin{abstract}
Energy demand increases continuously due to the growth of industries. Most industries still rely on fossil fuel that its price commonly increases and the deposit in the universe decreases since it is not renewable resource. Indonesia is the largest palm oil producer in the world that has potential abundance biomass of empty fruit bunch (EFB) of oil palm. It can be alternative energy source. The EFB is commonly used as fuel for heat source of boiler jn the palm oil plant. Most applications were by conventional combustion process that has disadvantage of low energy value. The EFB was only chopped and grinded, and then dried prior to combustion process. This study investigates improvement of energy quality of EFB through torrefaction (or light pyrolysis) and densification process. The EFB was chopped in the small size and grinded in the form of fiber, then dried. The EFB fiber in small slices was pressed in a small steel tube and heated in the range of $200-300^{\circ} \mathrm{C}$. The variables of study were duration and temperature of process. The initial heat value of EFB was 18,241 MJ/kg that slightly lower than its of kernel shell heat value $19.955 \mathrm{MJ} / \mathrm{kg}$. The water content were found $6.28 \%$ and $4.31 \%$ for EFB and kernel shell respectively. Results have shown that torrefaction and densification have improved the calorific value of EFB in the range of 6.58-16.71\% of its initial value. On the other hand, the energy yield has decreased to $97.54,97.26$ and $93.76 \%$ of its initial energy yield for torrefaction temperature of 200,250 and $300^{\circ} \mathrm{C}$ respectively
\end{abstract}

Key words: empty fruit bunch, oil palm, solid fuel, torrefaction, calorific value.

\section{Pendahuluan}

Pertumbuhan industri yang pesat telah menimbulkan konsumsi energi yang sangat besar. Kebutuhan energi industri di Indonesia pada umumnya masih dipasok oleh bahan bakar minyak maupun gas. Di sisi lain, bahan bakar minyak merupakan bahan impor diIndonesia dengan harga cukup tinggi. Industri kecil pada umumnya memiliki kendala di bagian penyediaan energi. Industri kecil hampir tidak mungkin menggunakan sumber energi dari bahan bakar minyak, karena secara ekonomi akan sangat rugi. Indonesia memiliki potensi biomassa yang sangat besar dan mungkin untuk dimanfaatkan sebagai sumber energy alternatif sebagai pengganti bahan bakar fosil atau bahan bakar minyak. Biomassa dihasilkan dari berbagai kegiatan perkebunan seperti kebun kelapa sawit dan hutan tanaman industri.

Sumber biomassa terbesar di antaranya disumbangkan oleh perkebunan kelapa sawit. Kelapa sawit merupakan tumbuhan pohon yang tingginya bisa mencapai 24 meter. Bunga dan buahnya berupa tandan serta bercabang banyak. Buahnya kecil dan berwarna merah kehitaman apabila masak. Daging buahnya padat. Kulit buah dan daging buah mengandung minyak. Buah sawit menempel pada tandan buah. Buah sawit terdiri dari lapisan eksokarp: bagian kulit buah yang berwarna kemerahan dan licin, lapisan mesokarp: bagian serabut buah, endoskarp: cangkang buah dan endosperm/inti buah dan embrio yang mengandung minyak inti berkualitas tinggi 
Chemica

Volume 1, Nomor 2, Desember 2014, 77-84

ISSN : 2355-8776

[1]. Minyak sawit terkandung dalam serabut buah (mesokarp) yang biasa disebut crude palm oil (CPO) dan inti sawit mengandung minyak inti sawit atau kernel palm oil (KPO).

Tandan kosong kelapa sawit adalah tandan buah kelapa sawit yang telah diambil buahnya melalui proses pemipilan atau threshing. Proses pengolahan kelapa sawit dapat disajikan pada Gambar 1 [2]. Kelapa sawit menghasilkan produk berupa minyak sawit, dan limbah berupa tandan kosong kelapa sawit dan cangkang sawit. Potensi tandan kosong kelapa sawit di Indonesia mencapai 11.7 juta ton pada tahun 2011 [3].

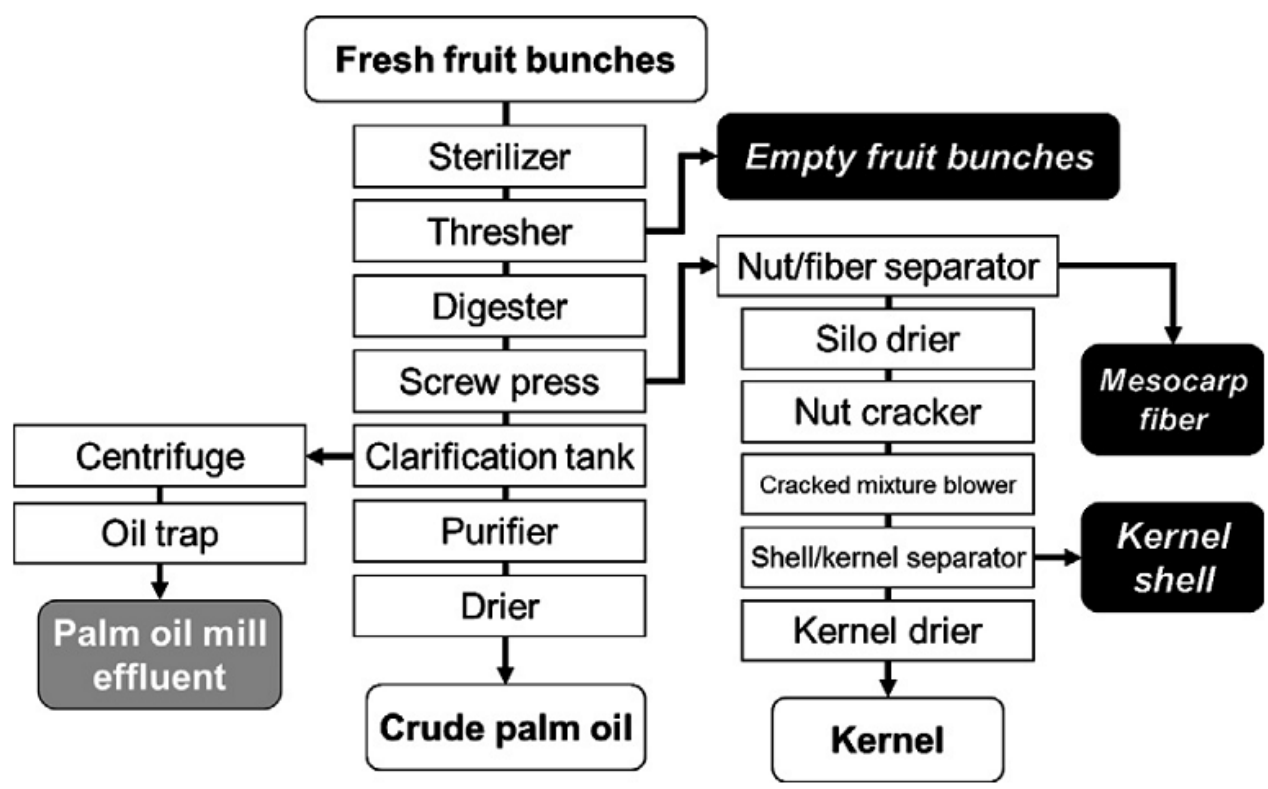

Gambar 1. Proses pengolahan kelapa sawit (Sumber: Uemura et al., 2011)

Potensi kelapa sawit di Indonesia sangat besar yang tersebar di seluruh wilayah, terutama Sumatera dan Kalimantan. Produksi minyak sawit Indonesia tumbuh dari 21.390.326 ton tahun 2009 menjadi 22.899.109 ton tahun 2011[4]. Sebaran produsen utama minyak sawit (Crude Palm Oil/CPO) berdasarkan provinsi disajikan pada Tabel 1. Produksi minyak sawit yang besar juga memberikan gambaran betapa besar limbah biomassa yang dihasilkan. Limbah biomassa kelapa sawit dapat dilihat di dua tahapan, di kebun kelapa sawit (on farm) dan di pabrik kelapa sawit (off farm), potongan pelepah, batang pohon kelapa sawit dan limbah tandan kosong kelapa dari pabrik CPO.

Tandan kosong kelapa sawit selama sudah dimanfaatkan sebagai bahan bakar boiler, namun pemanfaatanya belum maksimal. Karakteristik tandan kosong berbeda dengan cangkang dan serabut, hal ini menyebabkan tandan kosong tidak dapat digunakan sebagai sumber energi secara langsung dengan menggunakan fasilitas yang sama dengan cangkang dan serabut. Karakteristik yang berbeda dari tandan kosong, menyebabkan dibutuhkannya teknologi yang khusus dalam pemanfaatannya sebagain bahan bakar [5].

Tabel 1. Produksi minyak sawit (ton) di Indonesia

\begin{tabular}{|l|c|c|c|}
\hline \multicolumn{1}{|c|}{ Provinsi } & $\mathbf{2 0 0 9}$ & $\mathbf{2 0 1 0}$ & $\mathbf{2 0 1 1}$ \\
\hline Sumatera Utara & 3862399 & 3899623 & 4001150 \\
\hline Riau & 5311368 & 5495968 & 5391303 \\
\hline Jambi & 1499891 & 1644086 & 1690990 \\
\hline Sumatera Selatan & 2313508 & 2542822 & 2481090 \\
\hline Kalimantan Barat & 1331659 & 1426876 & 1408629 \\
\hline Kalimantan Tengah & 1798102 & 1724668 & 2115445 \\
\hline Kalimantan Selatan & 1041367 & 1049219 & 1029141 \\
\hline
\end{tabular}

Sumber: (BPS,2012) 
Torrefaksi adalah metode termal untuk konversi biomassa yang beroperasi pada suhu $200-300{ }^{\circ} \mathrm{C}$. Proses ini dilakukan pada kondisi atmosferis tanpa adanya oksigen. Nama lain dari proses torrefaksi adalah roasting, slow-and mild pyrolysis, wood cooking dan pengeringan suhu tinggi. Torrefaksi adalah adalah teknologi yang dapat meningkatkan sifat-sifat biomassa [6]. Densifikasi adalah proses pemadatan biomassa dengan tekanan tertentu. Wang [7] melakukan kombinasi torrefaksi dan densifikasi sisa gergaji menjadi pelet. Pelet yang dihasilkan memiliki kualitas yang bagus.

Pemanfaatan limbah tandan kosong kelapa sawit masih sangat terbatas. Di sisi lain hidupnya industri kecil sangat ditentukan oleh pemenuhan kebutuhan energi. Beberapa pabrik kelapa sawit skala kecil hanya mengolah tandan kosong kelapa sawit dengan menggiling dan mengeringkan. Kemudian bahan tersebut dibakar biasa. Hal ini memberikan kandungan energi per volumenya rendah. Selain itu pembakaran secara sederhana juga mengakibatkan sulit untuk mengendalikan panas yang dihasilkan. Oleh karena itu perlu dilakukan usaha untuk menghasilkan bahan bakar padat berbasis limbah tandan kosong kelapa sawit yang memiliki kualitas yang baik.

Penelitian ini dirancang untuk meningkatkan kualitas tandan kosong kelapa sawit sebagai bahan bakar melalui proses torrefaksi (pemanasan) dan densifikasi (pemadatan). Proses ini diharapkan akan menghasilkan bahan bakar padat yang memiliki kandungan panas per satuan volume yang lebih besar, pembakaran yang stabil, efisiensi pembakaran yang lebih baik.

\section{Metode Penelitian}

Bahan: bahanutama adalahtandan kosong kelapa sawit. Tandan kosong kelapa sawit (TKKS) yang sudah diolah berupa serat/fiber yang didatangkan dari pabrik kelapa sawit di Indragiri Hilir, Riau.

Alat: alat penelitian yang digunakan pada percobaan pendahuluan adalah alat pemotong untuk memotong serat tandan kosong kelapa sawit menjadi lebih pendek. Oven digunakan untuk mengeringkan serat dari tandan kosong kelapa sawit. Thermogravimetric Analyzer (TGA) digunakan untuk menentukan rentang suhu operasi torrefaksi. Sedangkan alat utama adalah alat pres hidrolik berupa cetakan silinder yang dilengkapi dengan pemanas, pengukur suhu dan pengukur tekanan. Alat uji tekan digunakan untuk mengukur kuat tekan bahan bakar padat hasil torrefaksi dan densifikasi. Alat uji kandungan panas bahan bakar padat hasil torrefaksi dan densifikasi.

Prosedur penelitian: prosedur secara umum dapat dilihat pada Gambar 2. Tandan kosong kelapa sawit yang sudah berupa serat/fiber dipotong-potong menjadi ukuran kecil $0,5-1 \mathrm{~cm}$. Potongan serat tandan kosong kelapa sawit dikeringkan dalam oven pada suhu $60{ }^{\circ} \mathrm{C}$ selama 3-4 jam.

Sebagian kecil bahan diambil untuk diuji thermogravimetry dan kandungan panas. Selanjutnya bahan dimasukkan dalam cetakan alat pres untuk dilakukan densifikasi (pengepresan) dan torrefaksi (pemanasan) secara simultan. Suhu pemanasan ditentukan dari hasil uji thermogravimetry diperkirakan berkisar $200-300^{\circ} \mathrm{C}$. Tekanan proses dilakukan eksplorasi dengan meningkatkan penekanan sampai bahan padat dimampatkan secara maksimal. Variabel yang diteliti meliputi suhu proses dan lama proses. Pengujian heat value dilakukan pada hasil torrefaksi dan densifikasi secara simultan dengan alat bomb-calorimeter untuk memperoleh nilai kalor setiap satuan berat.

Analisis hasil: analisis meliputi kekuatan mekanik bahan bakar padat dan kandungan panas bahan bakar padat. Kondisi terbaik dicari untuk memberikan hasil bahan bakar padat kandungan panas yang tinggi. Grafik hubungan variabel (suhu proses, waktu) dengan hasil (respon) berupa heat value (kandungan panas) akan memberikan gambaran kondisi operasi yang memberikan hasil terbaik. 


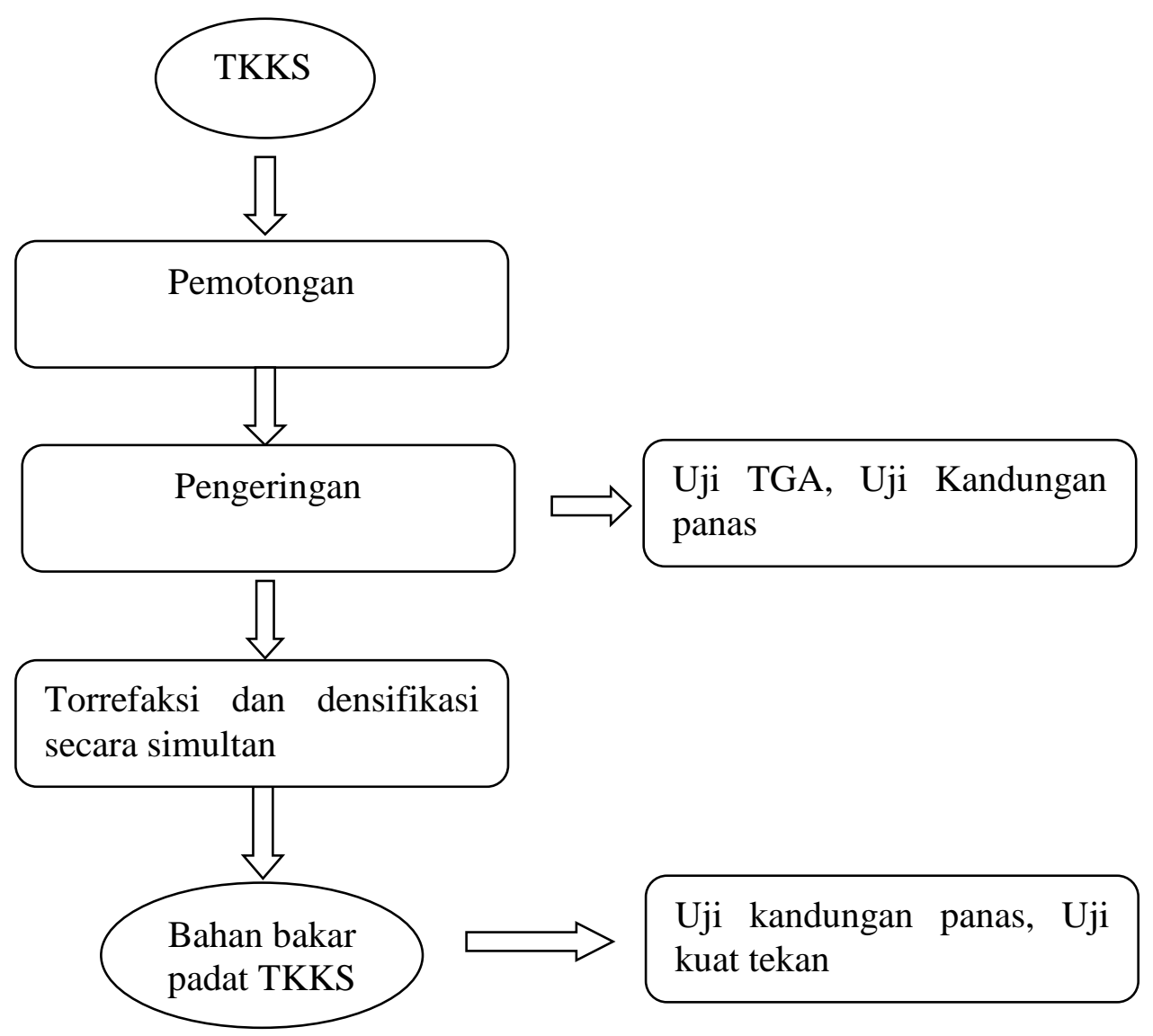

Gambar 2. Diagram alir penelitian

\section{Hasil dan Pembahasan}

\section{Karakteristik Tandan Kosong Kelapa Sawit}

Karakterisasi serat tandan kosong kelapa sawit telah dilakukan dengan mengukur kadar air, kadar fixed carbon, kadar volatile. Selain itu pengukuran terhadap parameter-parameter tersebut juga dilakukan terhadap cangkang buah kelapa sawit. Hal ini karena selama ini cangkang buah dinilai lebih baik sebagai sumber bahan bakar karena sifatnya yang keras dan padat.

Analisis kadar air menunjukkan fiber dari tandan kosong kelapa sawit memiliki kandungan air sekitar $6,28 \%$. Sementara cangkang kelapa sawit (palm kernel shell) mengandung air sedikit lebih rendah sekitar 4,31 $\%$.

Analisis thermogravimetri (TG) menunjukkan hasil seperti disajikan pada Gambar 3, sementara bentuk derivative thermogravimetri (DTG) disajikan pada Gambar 4. Gambar 3 dan 4 menunjukkan bahwa baik fiber dari tandan kosong kelapa sawit maupun cangkang kelapa sawit mengalami beberapa langkah degradasi (multiple steps degradation)selama proses pemanasan. Hal ini bisa dilihat adanya beberapa puncak dalam kurva DTG (Gambar 4). Namun, proses utama degradasi terjadi pada rentang suhu $200-400{ }^{\circ} \mathrm{C}$. Pada awal proses ditandai dengan pelepasan air yang terkandung dalam fiber/serat, selanjutnya pada proses degradasi utama akan melepaskan zat-zat volatile yang lain yang memiliki titik penguapan lebih tinggi. Selain itu juga terjadi dekomposisi yang menghasilkan asam asetat, furfural, hydroxiacetone sebagaimana dilaporkan sebelumnya oleh Pathwardhan et al. [8]. 


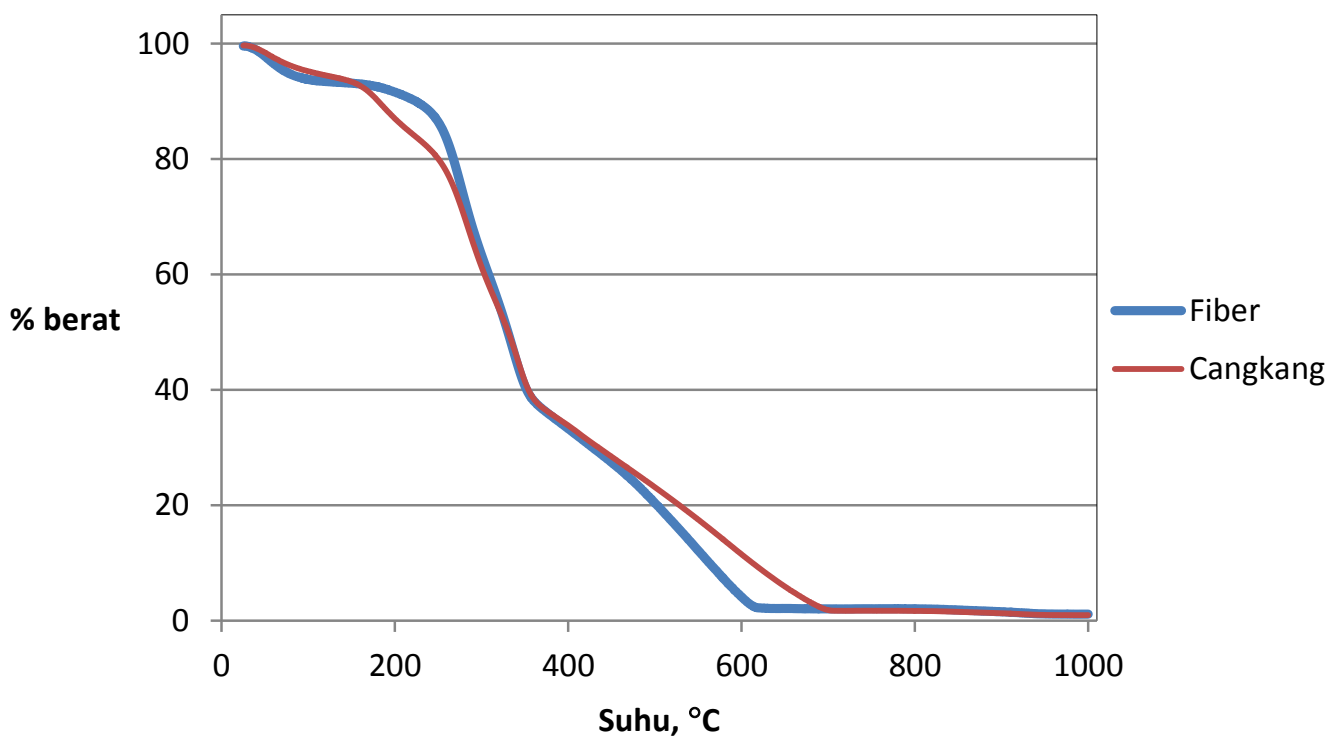

Gambar 3. Grafik thermogravimetri (TG) dari fiber tandan kosong dan cangkangkelapa sawit

Hasil tes thermogravimetri (TG) dan derivatif thermogravimetri (DTG) juga memberikan gambaran bahwa antara fiber/serat dari tandan kosong kelapa sawit dan cangkang (kernel shell) tidak ada perbedaan yang signifikan dalam sifat degradasinya. Hal ini ditunjukkan dari kurva yang hampir sama, menunjukan langkah degradasi dan suhu degradasi yang hampir sama.

Kurva thermogravimetri (TG) dan derivatif thermogravimetri (DTG) dijadikan acuan untuk menentukan kondisi operasi torrefaksi. Kondisi proses torrefaksi dilakukan pada tahap awal terjadinya degradasi utama. Maka rentang suhu $200-300{ }^{\circ} \mathrm{C}$ dipilih untuk melakukan proses torrefaksi.

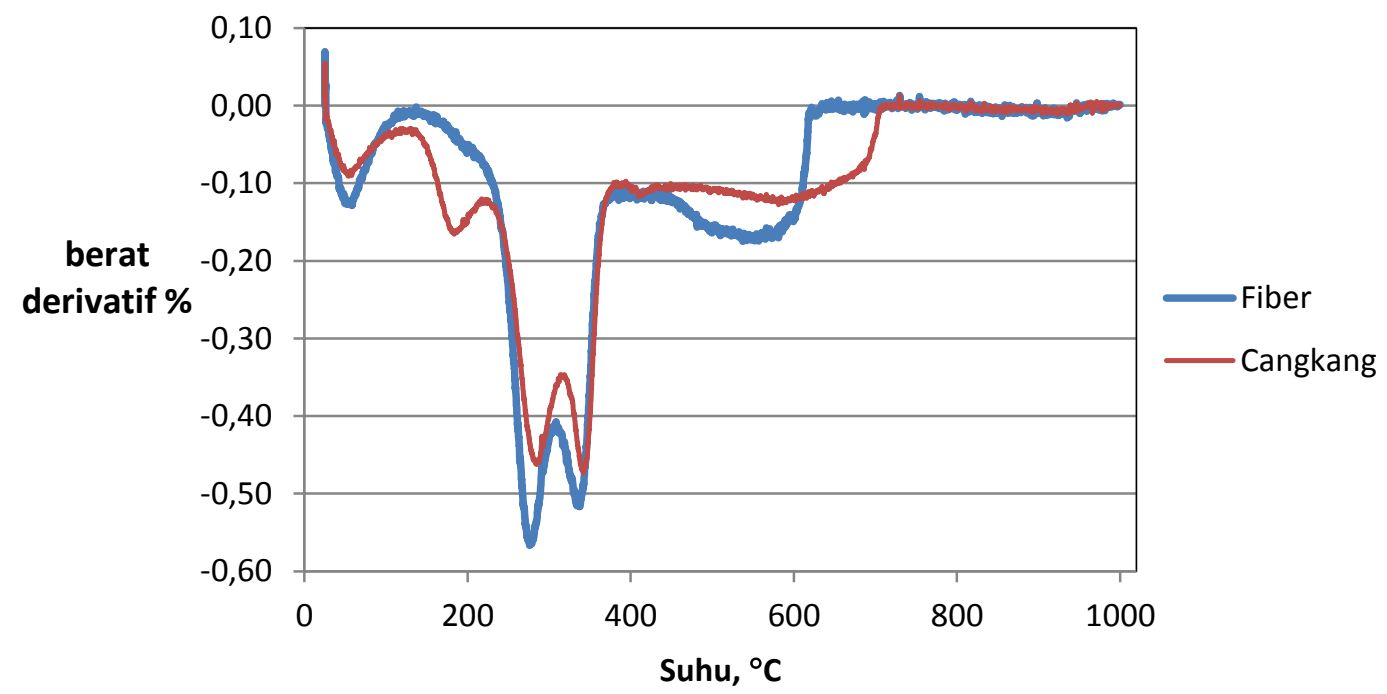

Gambar 4. Grafik thermogravimetri derivatif (DTG) dari fiber tandan kosong dan cangkangkelapa sawit

\section{Karakteristik Torrefaksi}

Torrefaksi dilaksanakan pada rentang suhu $200-300{ }^{\circ} \mathrm{C}$, sesuai dengan hasil pengujianthermogravimetri (TG). Nilai panas (calorific value /heat value) setelah proses torrefaksi ditampilkan dalam Tabel 2 dan Gambar 5. 
Selain itu uji calorific value juga dilakukan pada cangkang (kernel shell) tanpa proses torrefaksi. Calorific value cangkang sebesar $19.955 \mathrm{MJ} / \mathrm{kg}$ lebih besar sedikit dibanding calorific value fiber sebesar $18,241 \mathrm{MJ} / \mathrm{kg}$.

Tabel 2. Data calorific value (nilai kalor) fiber setelah torrefaksi pada berbagai suhu dan waktu proses

\begin{tabular}{|c|c|c|c|}
\hline \multirow{2}{*}{ Waktu, menit } & \multicolumn{3}{|c|}{ Calorific Value, MJ/kg } \\
\cline { 2 - 4 } & $\mathrm{T}=200{ }^{\circ} \mathrm{C}$ & $\mathrm{T}=250^{\circ} \mathrm{C}$ & $\mathrm{T}=300{ }^{\circ} \mathrm{C}$ \\
\hline 0 & 18,241 & 18,241 & 18,241 \\
\hline 15 & 18,512 & 19,002 & 19,314 \\
\hline 30 & 19,072 & 19,483 & 20,835 \\
\hline 45 & 19,132 & 20,403 & 21,321 \\
\hline 60 & 19,442 & 20,522 & 21,289 \\
\hline
\end{tabular}

Hasil menunjukkan bahwa kondisi waktu dan suhu torrefaksi berpengaruh pada kandungan panas atau calorific value (CV). Semakin lama proses torrefaksi akan meningkatkan kandungan panas. Gambar 5 menunjukkan waktu sekitar 45 menit memberikan hasil yang optimum. Setelah 45 menit, nilai kandungan panas atau CVrelatif tidak berubah.

Perubahan suhu proses juga memberikan pengaruh pada calorific value. Gambar 5 menunjukkan bahwa semakin tinggi suhu semakin besar calorific value (CV). Pada suhu $300{ }^{\circ} \mathrm{C}$ memberikan peningkatan yang terbesar, dari calorific value (CV) 18,241 MJ/kg sebelum torrefaksi menjadi 21,289 MJ/kg setelah proses torrefaksi. Suhu yang tinggi memberikan proses pembebasan bahan volatile yang lebih sempurna, sehingga kandungan atau persentase fixed carbon dalam hasil akan semakin besar. Hal ini berarti meningkatkan kandungan panas atau calorific value $(\mathrm{CV})$. Calorific value $(\mathrm{CV})$ yang tinggi berarti semakin baik untuk penerapan sebagai bahan bakar, dengan volume yang kecil tetapi memberikan nilai panas yang besar.

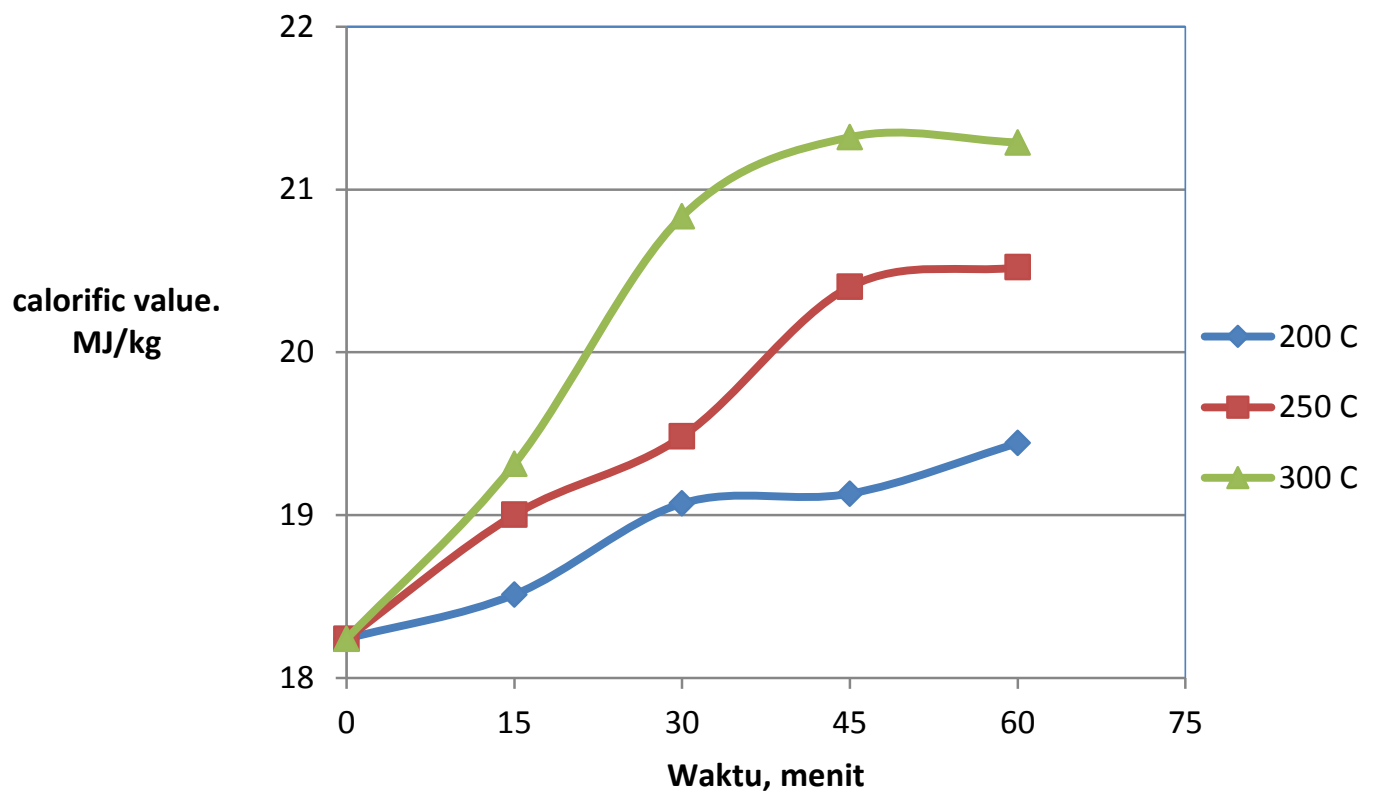

Gambar 5. Grafik hubungan calorific value (heat value) dengan waktu torrefaksi.

Uemura et. al. [2] menggunakan istilah calorific value ratio atau CV ratio untuk menyatakan perbandingan antara calorific value sebelum proses torrefaksi dengan sesudah proses torrefaksi. Calorific value ratio disajikan pada Tabel 3. CV ratio naik sesuai dengan kenaikan suhu proses torrefaksi. Setelah proses torrefaksi selama 60 menit, CV ratio naik 6,58 \%, 12,50\% dan 16,71\% berturutan untuk suhu 200, 250 dan 300 ${ }^{\circ} \mathrm{C}$. 
Tabel 3. Data calorific value ratio dari fiber setelah torrefaksi pada berbagai suhu dan waktu proses

\begin{tabular}{|c|c|c|c|}
\hline \multirow{2}{*}{ Waktu, menit } & \multicolumn{3}{|c|}{ Calorific Value ratio (CV ratio), \% } \\
\cline { 2 - 4 } & $\mathrm{T}=200{ }^{\circ} \mathrm{C}$ & $\mathrm{T}=250{ }^{\circ} \mathrm{C}$ & $\mathrm{T}=300{ }^{\circ} \mathrm{C}$ \\
\hline 0 & 100 & 100 & 100 \\
\hline 15 & 101,49 & 104,17 & 105,88 \\
\hline 30 & 104,56 & 106,81 & 114,22 \\
\hline 45 & 104,88 & 111,85 & 116,89 \\
\hline 60 & 106,58 & 112,50 & 116,71 \\
\hline
\end{tabular}

Selain calorific value, hal yang penting untuk diamati adalah enegy yield. Energy yield merupakan kasil kali mass yield dengan CV ratio [2]. Energy yield menyatakan energy yang diperoleh dari proses torrefaksi. Energy yield disajikan pada Tabel 4 dan ditampilkan dalam Gambar 6.

Tabel 4. Data energi yield pada berbagai suhu setelah proses torrefaksi selama 60 menit

\begin{tabular}{|c|c|c|c|}
\hline Suhu Proses, ${ }^{\circ} \mathrm{C}$ & CV ratio, $\%$ & Mass yield & Energy Yield, $\%$ \\
\hline 200 & 106,58 & 0,9151 & 97,54 \\
\hline 250 & 112,50 & 0,8642 & 97,26 \\
\hline 300 & 116,71 & 0,8034 & 93,76 \\
\hline
\end{tabular}

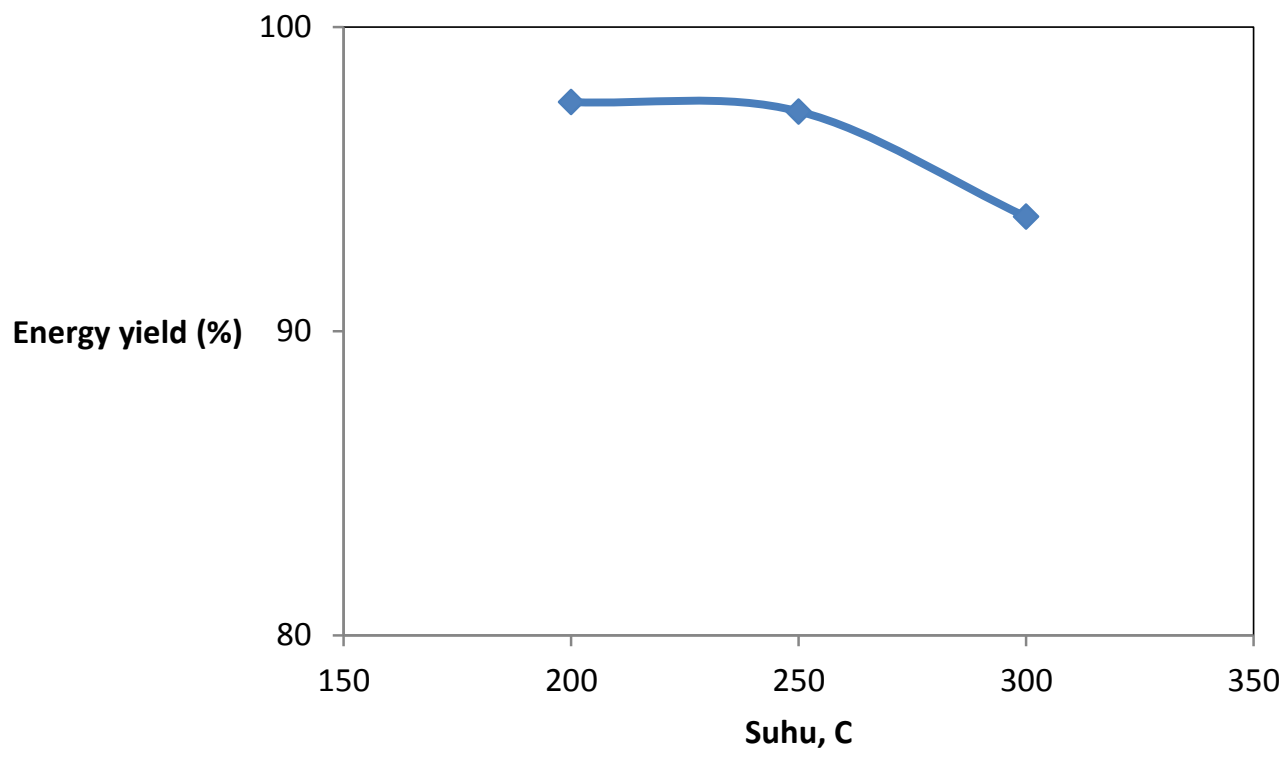

Gambar 6. Grafik hubungan energy yield dan suhu torrefaksi.

Gambar 6 menunjukkan bahwa energy yield turun dengan naiknya suhu proses torrefaksi. Di sisi lain, seperti dibahas sebelumnya bahwa calorific value naik dengan naiknya suhu proses torrefaksi (Gambar 5). Hal ini menunjukkan bahwa naiknya suhu proses torrefaksi bisa memberikan keuntungan bahwa bahan memiliki calorific value yang tinggi, namun ada kerugian yaitu turunnya energy yield, atau ada kehilangan potensi energy dari bahan.

\section{Simpulan dan Saran}

\section{Simpulan}

Karakterisasi bahan dan torrefaksi telah dilaksanakan pada berbagai kondisi. Dari pembahasan dapat ditarik simpulan a) fiber dari tandan kosong kelapa sawit memiliki sifat yang hampir sama dengan cangkang kelapa sawit, baik kandungan air, kandungan energy dan sifat degradasi; b) calorific value fiber pada kondisi 
Chemica

Volume 1, Nomor 2, Desember 2014, 77-84

ISSN : 2355-8776

awal sebesar 18,241 MJ/kg lebih kecil sedikit dibanding calorific value cangkang sebesar $19.955 \mathrm{MJ} / \mathrm{kg}$; c) kenaikan suhu proses torrefaksi mengakibatkan naiknya calorific value, namun energy yield berkurang. Torrefaksi memiliki keuntungan peningkatan kualitas bahan bakar padat, tetapi menurunkan kandungan energy (energy yield).

\section{Saran}

Pengujian kuat tekan perlu dilakukan untuk mengetahui kekuatan briket yang dihasilkan. Penelitian torrefaksi bisa dilanjutkan untuk mempelajari proses dan kondisi operasi yang memberikan kekuatan tekan yang baik.

\section{Daftar Pustaka}

[1] Depratemen Perindustrian, 2007, Gambaran Sekilas Industri Minyak Kelapa Sawit, Sekretaris Jenderal Departemen Perindustrian, Jakarta.

[2] Uemura, Y., Omar, W.N., Tsutsui, T. and Yusup, S.B. 2011. Torrefaction of oil palm wastes. Fuel. 90(8): 2585-2591.

[3] Cahyanto, M.N., 2012, Penelitian Kelapa Sawit Di Fakultas Teknologi Pertanian Universitas Gadjah Mada, Seminar Kelapa Sawit, FTP-UGM, Yogyakarta

[4] BPS, 2012, Perkembangan Beberapa Indikator Utama Sosial-Ekonomi Indonesia, Badan Pusat Statistik, Jakarta, Indonesia. p.71

[5] Fabijanto, I., 2011, Kajian Teknis \& Keekonomian Pembangkit Listrik Tenaga Biomasa Sawit; Kasus: Di Pabrik Kelapa Sawit Pinang Tinggi, Sei Bahar, Jambi, Journal of Mechatronics, Electrical Power, and Vehicular Technology, Vol. 02, No 1, pp 11-22.

[6] Van der Stelt, M.J.C., Gerhauser, H., Kiel, J.H.A. and Ptasinski, K.J. 2011. Biomass upgrading by torrefaction for the production of biofuels: A review. Biomass and Bioenergy. 35(9): 3748-3762.

[7] Wang, C., Peng, J., Li, H., Bi, X.T., Legros, R., Lim, C.J. and Sokhansanj, S. 2013. Oxidative torrefaction of biomass residues and densification of torrefied sawdust to pellets. Bioresource Technology. 127(0): 318325 .

[8] Patwardhan, P.R., Brown, R.C., Shanks, B.H., 2011. Product distribution from the fast pyrolysis of hemicellulose. ChemSusChem 4, 636-643. 